\title{
Water Sensitive Cities: An Integrated Approach to Enhance Urban Flood Resilience in Parma (Northern Italy)
}

\author{
Arianna Dada ${ }^{1, *(\mathbb{D}}$, Christian Urich $^{2}$, Francesca Berteni ${ }^{1} \mathbb{D}$, Michèle Pezzagno $^{1}\left(\mathbb{D}\right.$, Patrizia Piro $^{3}$ \\ and Giovanna Grossi ${ }^{1}$ (D)
}

1 Department of Civil, Environmental, Architectural Engineering and Mathematics, University of Brescia, Via Branze 43, 25123 Brescia, Italy; francesca.berteni@unibs.it (F.B.); michele.pezzagno@unibs.it (M.P.); giovanna.grossi@unibs.it (G.G.)

2 Department of Civil Engineering, Monash University of Melbourne, Wellington Road, Melbourne, VIC 3800, Australia; christian.urich@monash.edu

3 Department of Civil Engineering, University of Calabria, Via P. Bucci-Cubo 45B, 87036 Rende, Italy; patrizia.piro@unical.it

* Correspondence: a.dada@unibs.it

check for updates

Citation: Dada, A.; Urich, C.; Berteni, F.; Pezzagno, M.; Piro, P.; Grossi, G. Water Sensitive Cities: An Integrated Approach to Enhance Urban Flood Resilience in Parma (Northern Italy). Climate 2021, 9, 152. https:// doi.org/10.3390/cli9100152

Academic Editor: Chris Swanston

Received: 22 September 2021

Accepted: 13 October 2021

Published: 16 October 2021

Publisher's Note: MDPI stays neutral with regard to jurisdictional claims in published maps and institutional affiliations.

Copyright: (c) 2021 by the authors. Licensee MDPI, Basel, Switzerland. This article is an open access article distributed under the terms and conditions of the Creative Commons Attribution (CC BY) license (https:// creativecommons.org/licenses/by/ $4.0 /)$.

\begin{abstract}
Climate change is globally causing more intense meteorological phenomena. Our cities experience increased rainfall intensity, more intense heat waves, and prolonged droughts providing economic, social, health and environmental challenges. Combined with population growth and rapid urbanization, the increasing impact of climate change will make our cities more and more vulnerable, especially to urban flooding. In order to adapt our urban water systems to these challenges, the adoption of newly emerging water management strategies is required. The complexity and scale of this challenge calls for the integration of knowledge from different disciplines and collaborative approaches. The water sensitive cities principles provide guidance for developing new techniques, strategies, policies, and tools to improve the livability, sustainability, and resilience of cities. In this study, the DAnCE4Water modeling approach promoting the development of water sensitive cities was applied to Parma, an Italian town that has faced serious water issues in the last few years. The city, indeed, had to face the consequences of flooding several times, caused by the inadequacy of both the network of open channels and the sewerage network due to the urban expansion and climate change of the last 30 years. Through the model, the efficiency of decentralized technologies, such as green roofs and porous pavement, and their integration with the existing centralized combined sewer system was assessed under a range of urban development scenarios. The obtained results show that the adoption of an integrated approach, including soft engineering hydraulic strategies, consisting in the use of natural and sustainable solutions, can increase resilience to urban flooding. Further, the study shows that there is a critical need for strategic investment in solutions that will deliver long-term sustainable outcomes.
\end{abstract}

Keywords: water sensitive cities; water sensitive urban design; sustainable urban drainage; urban planning; SWMM; flood risk; DAnCE4Water

\section{Introduction}

Changes in climate and urbanization are two of the most important factors that impact urban flood risks. Urbanization, to which population growth is associated, increases the rate of impervious surfaces, thus increasing urban runoff and flood risk [1]. Climate change increases the frequency and the magnitude of rainfall and consequently that of surface runoff, often exceeding the limited design capacity of the existing infrastructure [2]. These combined impacts have been shown to lead to more frequent and devasting flooding events, compromising the resilience of urban drainage systems [3-5]. Traditional drainage systems and classical approaches have proved ineffective in countering the effects of these phenomena. 
Emerging approaches, like the concept of water sensitive cities (WSC), provide an alternative approach that tackles these challenges by integrating urban planning and environmental engineering, social science, and community engagement, developing new technologies, strategies, policies, and tools that aim to improve the livability, sustainability, and resilience of cities [6,7].

The concept of WSC emerged originally in Australia and was driven by environmental pollution caused by untreated stormwater runoff, aging, and the inadequacy of the urban infrastructure and water scarcity during the Millennium drought, which positioned water challenges at the top of political and community priorities [8]. The term "sensitivity" originates from the concept of water sensitive urban design (WSUD), which can be defined as a contemporary planning and engineering design approach that integrates urban planning with the management, protection, and conservation of the water cycle, and that ensures a sensitive urban water management to natural hydrological and ecological processes [9].

This approach, in addition to actively acting in surface runoff reduction, also integrates important aspects. such as ecological protection, water saving, and guarantees the good quality of water resources and water reuse for both domestic and recreational purposes $[10,11]$. Swales and infiltration trenches, permeable surfaces, water harvesting, green roofs, detention basins, wetlands, and ponds are some of the most important innovative techniques introduced by WSU [12]. As shown by Cristiano et al. [13], large-scale installation of rainwater harvesting systems combined with intensive green roofs could be an effective strategy to reduce and prevent urban flooding. Indeed, these systems are able to collect and store rainfall water, ensure biodiversity, lower the surface temperature through evapotranspiration [14], reduce pollution, and improve the urban aesthetic value [15-17].

An example of WSC concept application is Elwood, a suburb in Melbourne, Australia, which is vulnerable to pluvial and coastal flooding, where the interdisciplinary research activities to face flood risks were first analyzed. Results for this case study showed that the interdisciplinary approach enabled deeper and wider exploration of the opportunities for increasing flood resilience in Elwood. The development and analysis of flood mitigation options that best integrated into the urban environment were also supported by the involvement of different professionals and citizens [18].

Involving community, different stakeholders, and decision-makers to increase flood resilience works well, but it is still a challenge because it takes time and resources that may not be available [19]. Even though citizens remain generally unaware of the economic and environmental impacts of urban floods, their contribution is essential to identify new adaptation strategies [20]. Antwi et al. (2021) [21] examined stakeholders' perspectives of the second River Basin Management Plan for the management and governance of water resources in the Republic of Ireland. They concluded that stakeholder collaboration and awareness is necessary to achieve effective and efficient water policy measures, water quality systems, and water services network [21].

Another example of WSC implementation worthy of mention is that in the city of Innsbruck, Austria, where the effect of increased urbanization and increased rainfall intensities caused by climate change were examined. Considering these impacts, the flooding of the combined sewer system and an adaptation strategy, consisting of on-site infiltration system application, were analyzed. Results for this case study indicated that the installation of this adaptation strategy was not enough to compensate for the effects of climate change and land use change; therefore, supplementary measures are necessary in Innsbruck to ensure a good hydraulic performance of the sewerage [22-24].

This research aims to apply the WSC concept to Parma, an Italian town located in the Po Valley in the western area of the Emilian plain (Northern Italy), using the DAnCE4Water (Dynamic Adaptation for eNabling City Evolution for Water) model [22]. DAnCE4Water began as part of the "European Framework Program 7-PREPARED enabling change"; it was then adopted within "Program A (Society)" of the CRC for water sensitive cities, where it evolved into a cloud-based city modeling platform, Scenario Tool [25]. It is able to account for complex interactions between the hydraulic network and the urban environment and 
can simulate different scenarios of the development of the urban environment and water systems [23,26,27]. Flood risk modeling capabilities have limitations, and this is a crucial issue that is currently addressed by "Weak Points in the Flood Risk Modelling Chain", an initiative by the IAHR Committee on Flood Risk Management [28]. Therefore, this research could contribute positively to this initiative.

Interest in Parma arises from the severe water issues faced in recent years. The criticalities of its sewerage system are mostly due to the obsolescence of some of its parts and to the disordered urban expansions of the second post-war period. Nones and Pescaroli (2016) [29] analyzed the effects of flooding events and the adaptation of the European Floods Directive (2007/60/CE) [30], of which the goal is the reduction of flood risk consequences, considering different case studies, including Parma. This city was affected by a flooding event in October 2014, caused by heavy rainfalls and landslides, which caused economic damages and a breakdown in communication. This event is an example that shows flood directive gaps: new mitigation measures are necessary, and a stronger balance between hazard and vulnerability management is important to help water managers [29].

Parma was also selected because its characteristics (morphological conformation, dimensions, and the number of inhabitants) are in line with those of Elwood. In this analysis, the flood risk in Parma was evaluated under the following four different scenarios: (1) state-of-the-art without implementation of any adaptation strategy; (2) implementation with green roofs; (3) implementation of porous pavements; (4) new urban development areas without implementation of any adaptation strategy. Through the implementation of the DAnCE4Water model, the efficiency of new decentralized technologies (WSUD), through quantification of surface runoff reduction, and their integration with the existing water drainage network, were estimated.

This case study, despite the many uncertainties in modeling, represents a significant step forward in water drainage system planning. The integrated approach was employed both to test urban water management practices and to evaluate the capacity of mitigation measures to reduce surface runoff in different scenarios and under different conditions. This approach can, not only point out strengths and vulnerabilities that characterize the urban environment, but it can also help municipalities to more quickly identify better solutions to improve the resilience of a city.

Results show how the implementation of WSUD, green roofs, and porous pavement, in Parma can actively operate in the mitigation of the flood risk and therefore improve the resilience of the city. However, despite new tools being developed to support this work, they have not yet been widely used and the application is only in its infancy. Therefore, this paper is only a first challenge to test the integrated approach in the context of a European city, to rapidly evaluate the effectiveness of various strategy options with limited available data.

\section{Materials and Methods}

\subsection{Case Study}

Parma (Figure 1) is a town located in the north of Italy, which extends to the southern area of the Po River flood plain. The territory managed by the Municipality of Parma extends for about $261 \mathrm{~km}^{2}$ within the Parma Creek Basin. The city grew in the last 65 years from 122,978 to 193,315 inhabitants, or about $57 \%$-the highest national growth [31].

The Parma Creek, a tributary of the Po River, flows across the city from the south to the north. The altitude of the urban territory ranges from a minimum of $46 \mathrm{~m}$ a.s.l. to a maximum of $81 \mathrm{~m}$ a.s.l., while its slope varies between approx. $0.2 \%$ to $1 \%$ [32].

In the last century, the city was impacted several times by intense flood events, and, at the same time, faced a drought emergency in 2017. The city has a combined sewer system that is designed to collect stormwater, domestic sewage, and industrial wastewater in the same pipe network, but during heavy storms the additional stormwater might exceed the capacity of the sewer system at some sites, causing flooding. The hydraulic risk of the city is mostly linked to the urban expansion over the last fifty years and the consequent 
increase in impervious surfaces [33]. This issue is particularly pronounced in the areas on the east side of the sewer catchment. Especially in the last few years, the change of the land use due to urbanization made the average runoff coefficients shift from $0.05-0.1$ to $0.5-0.7$, with peaks of 0.9 in the case of settlements characterized by a prevalence of paved or covered areas (industrial areas, shopping centres, large roads) [33]. In the past, these criticalities were resolved through local interventions, such as canal path modification and channel coverage. As a consequence, some of these channels now collect both stormwater and wastewater, compromising the quality of surface water almost everywhere [33].

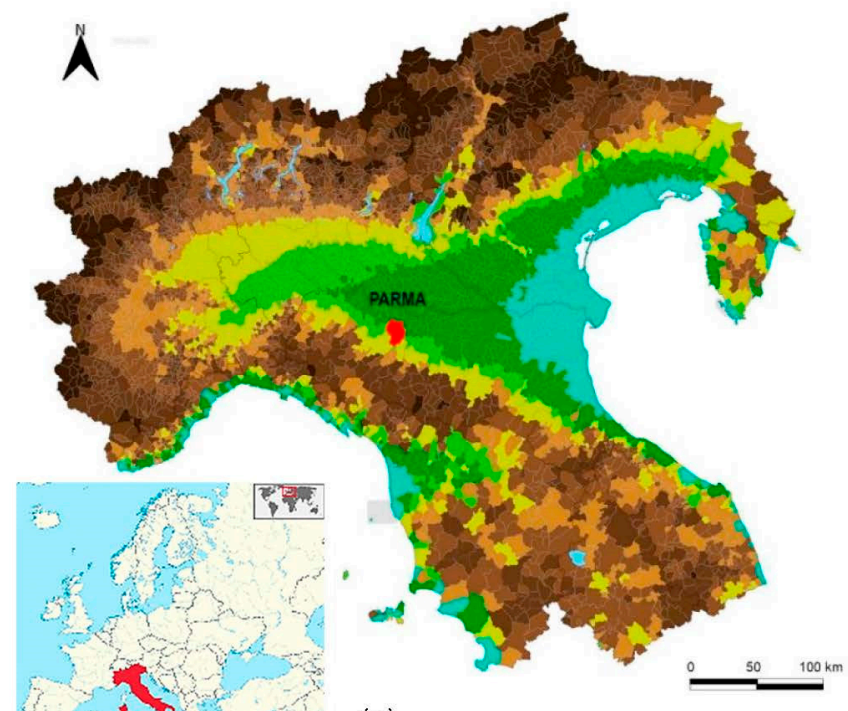

(a)

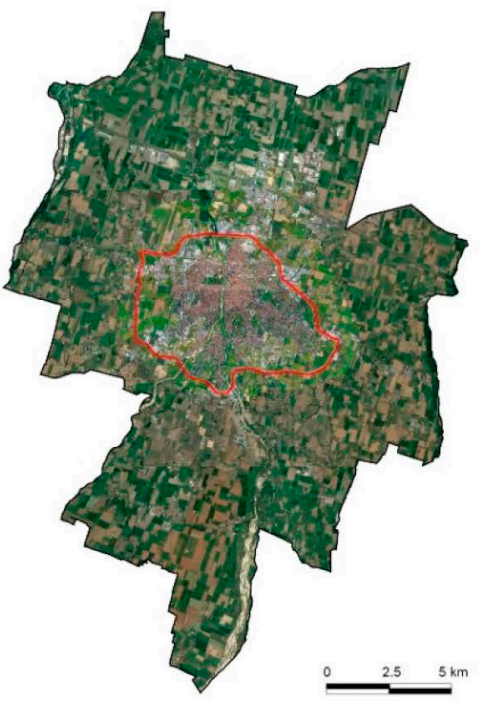

(b)

Figure 1. The study area of (a) map of Northern Italy showing the location of Parma; (b) boundaries of the territory managed by the municipality (urbanized area in red).

\subsection{Modeling and Analysis}

A computational decision-support tool was used to analyze the performance and test the efficiency of innovative drainage solutions and urban designs as flood risk mitigation measures in different development scenarios. This was enabled by scenario modeling, supported by DAnCE4Water's urban development algorithms, coupled with the EPA Storm Water Management Model (SWMM) [34], which assesses flood risk in time. The testing of mitigation measures for different potential scenarios is essential to identify a robust solution that account for the impacts of climate change.

Flood risk was assessed under four different scenarios:

- Business as usual (BAU), representing the current state without implementation of any adaptation measures;

- Porous pavement in which the model reduced the road fraction by $25 \%$;

- Green roof in which $25 \%$ of roofs are converted to green roofs;

- New urbanization, a scenario characterized by a new urban development. Urban growth was modeled by splitting the area into parcels and placing new buildings based on predefined preferences of location and building type, as well as high level drivers, such as population growth. Urban development layout details were accounted for in the SWMM model as changes in impervious areas, in the pipe network, or in the terrain.

\subsection{Hydraulic and Hydrologic Data and Simulation}

The preliminary hydrological analysis aimed at determining the flow rate in the catchment areas. Through the collection of meteorological data, the depth-durationfrequency (DDF) curves [35] were defined, as shown in Figure 2. This phase involved collecting data from ARPA Servizio Idro Meteo Clima, related to the Parma University 
rainfall station, located in the center of the town. The collected data refer to the period from 1952 to 2013 [36].

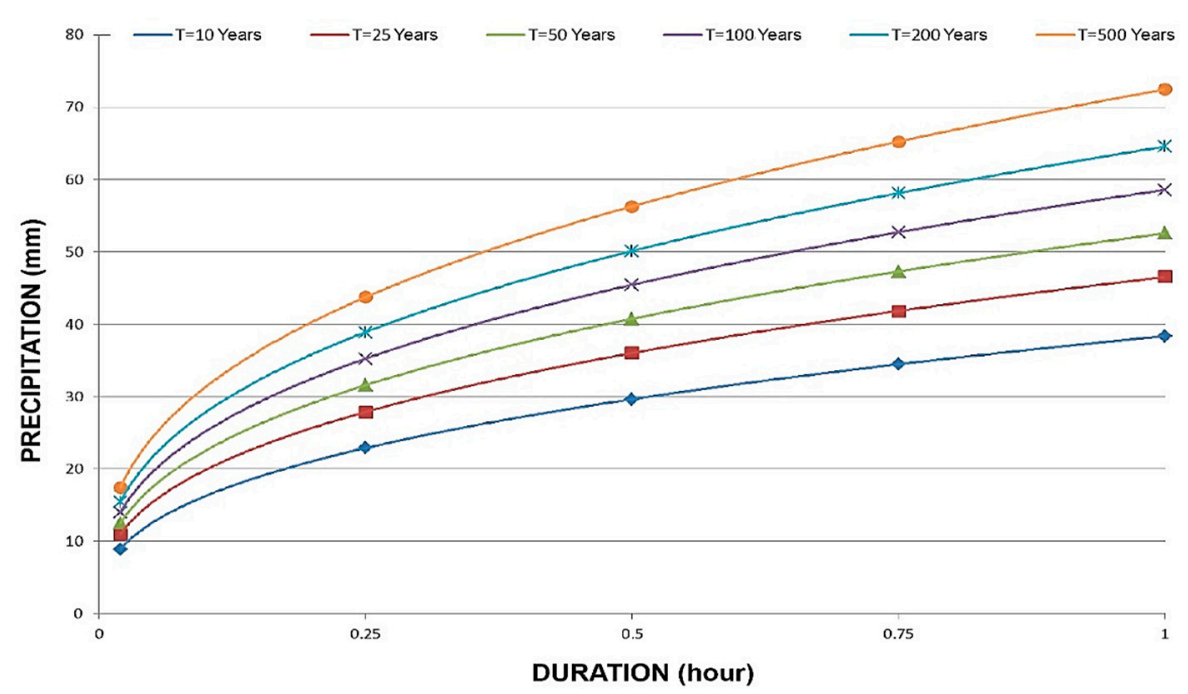

Figure 2. Depth-duration-frequency curves for Parma University station (duration up to $1 \mathrm{~h}$ ).

A designated storm was defined using DDF curves, assuming a duration of $60 \mathrm{~min}$ for the rainfall events. The rain events were described through a triangular hyetograph with a time step of $5 \mathrm{~min}$ (Figure 3). Hydrological determinations were carried out for a return periods of 25 years, to analyze the efficiency of the existing and planned sewage networks.

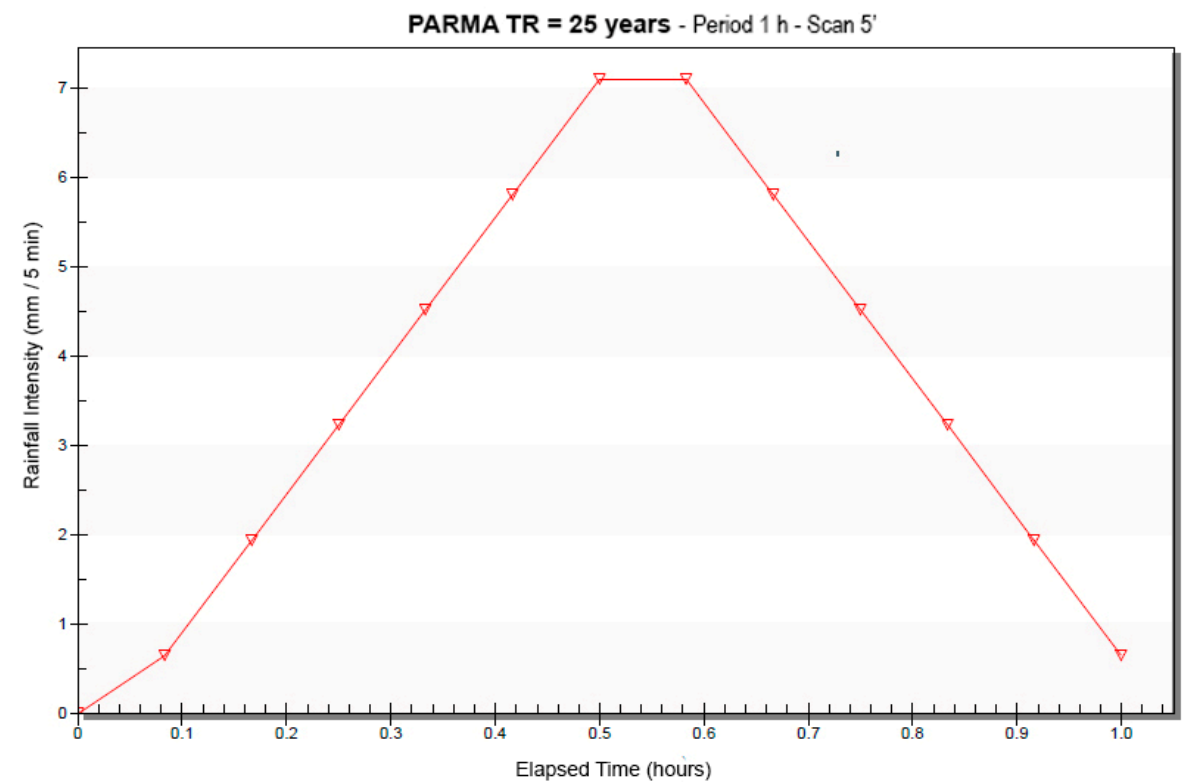

Figure 3. Design storm for a return period of 25 years and an event duration of $1 \mathrm{~h}$.

For the hydraulic-hydrological simulation, an extended time series of precipitation data (from 1952 to 2013) was used; no flow measurements for model calibration were available. Nevertheless, it should be noted that the runoff flow per unit area calculated using SWMM model in the study area was in line with the values measured by university researchers for different Italian experimental urban basins [37,38]. Flood hydrographs and peak flow rates calculated using SWMM, as described in Section 2.4, were assumed to be hypothetical current reference values with respect to future development scenarios. Namely, the performance of the basin-collector system was estimated in the current con- 
figuration, to assess the initial risk status and evaluate its potential reduction in different development scenarios.

\subsection{SWMM Model}

The hydraulic safety of a sewage systems depends on the relationship between their maximum capacity to dispose of hydrological events and the entity with which these can occur in the respective sub-catchment area. SWMM hydraulic and hydrologic modeling software was used to create a combined sewer system model, representing the sewerage system of the city.

As for the sub-basins, the SWMM model considers each of them as a non-linear tank with a single inlet of which the contribution comes from precipitation, and with multiple outlets that represent infiltration, evaporation, and surface runoff (Figure 4) [34]. The tank capacity represents the maximum storage capacity of the basin surfaces.
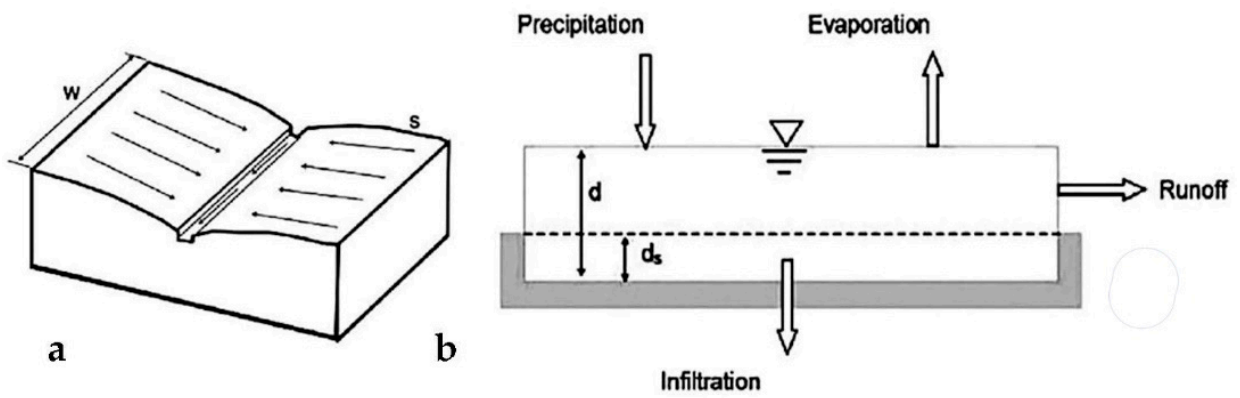

Figure 4. (a) Conceptualized subcatchment and (b) hydrological processes of the non-linear reservoir.

This process is mathematically represented by the solution of a differential equation system: DSaint Venant equations [39]. The continuity equation applied to each elementary area is:

$$
\frac{d V}{d t}=A \frac{d d}{d t}=A i^{*}-Q
$$

$V=\mathrm{A} \cdot \mathrm{d}=$ water volume in the subarea $\left(\mathrm{m}^{3}\right)$

$d=$ water height $(\mathrm{m})$

$t=$ time (s)

$A=$ sub-basin area $\left(\mathrm{m}^{2}\right)$

$i^{*}=$ precipitation intensity without evaporation and /or infiltration $(\mathrm{m} / \mathrm{s})$

$Q=$ flow velocity, $\mathrm{m}^{2} / \mathrm{s}$

It combines with the Manning's equation:

$$
Q=W \frac{1.49}{n}\left(d-d_{p}\right)^{5 / 3} S^{1 / 2}
$$

$W=$ width of the sub-basin $(\mathrm{m})$

$n=$ Manning's roughness coefficient

$d=$ water height $(\mathrm{m})$

$S=$ slope of the sub-basin $(\mathrm{m} / \mathrm{m})$

These two equations are combined in a non-linear differential equation, which can be solved with respect to an unknown, height $d$, of which the mathematical treatment is omitted for the sake of brevity. In the logic of the model, surface runoff begins only when the rainwater volume exceeds the sewer capacity and the surface accumulation capacity, while infiltration (only in the permeable portion of the surface) and evaporation continuously reduce the volume of water accumulated in the tank. If infiltration and evaporation are higher than precipitation, there is no outflow. Given the modest importance of the water 
balance during rain-induced urban flood events, the contribution due to evaporation was neglected. Instead, the infiltration was modeled according to Horton's equation [35].

$$
f_{p}=f_{c}+\left(f_{0}-f_{c}\right) e^{-k t}
$$

$f_{p}=$ infiltration capacity into soil $(\mathrm{mm} / \mathrm{hr})$;

$f_{c}=$ minimum or equilibrium infiltration rate at $\mathrm{t}=\infty(\mathrm{mm} / \mathrm{h})$;

$f_{0}=$ maximum or initial infiltration rate at $\mathrm{t}=0(\mathrm{~mm} / \mathrm{h})$;

$k=$ decay constant specific to the soil $\left(\mathrm{s}^{-1}\right)$;

$t=$ time from beginning of storm (s).

This hydrologic analysis was carried out for each schematic sub-basin and for each time computational step in which the time interval was divided. The model therefore uses a large number of parameters, to be defined for each sub-basin and for each collector that describes the network. The sub-basin outflow is then considered as an inflow to the node and is propagated as a one-dimensional water stream along the sewage collectors.

Flow routing within a conduit link is governed by the conservation of mass and momentum for gradually varied, unsteady flow (i.e., the Saint Venant flow equations). The calculation method chosen is the "dynamic wave", which defines the hydraulic parameters of the network in variable motion and, therefore, takes into account both the water reduction effects and the upstream and downstream dynamic conditions at each node of the network. In this analysis, a fundamental parameter is the Manning coefficient, $n$, of the collectors, which was set to $0.025 \mathrm{~s} / \mathrm{m}^{1 / 3}$, as is usually assumed for precast concrete in service and brick [40]. The simulation of the hydraulic behavior of the network includes a calculation of the water level in all nodes (wells) and the flow rate in all collectors for each time step in which the integration time interval of the differential equations was discretized. The reference events were simulated for a time period of $1 \mathrm{~h}$.

\subsection{DAnCE4Water and Scenario Tool}

DAnCE4Water is a strategic planning tool for modeling the complex interactions between societal dynamics, urban environment, and urban water system and infrastructures under different scenarios, such as climate and demographic changes, dynamics of water resources, and urban evolution (Figure 5) [27].

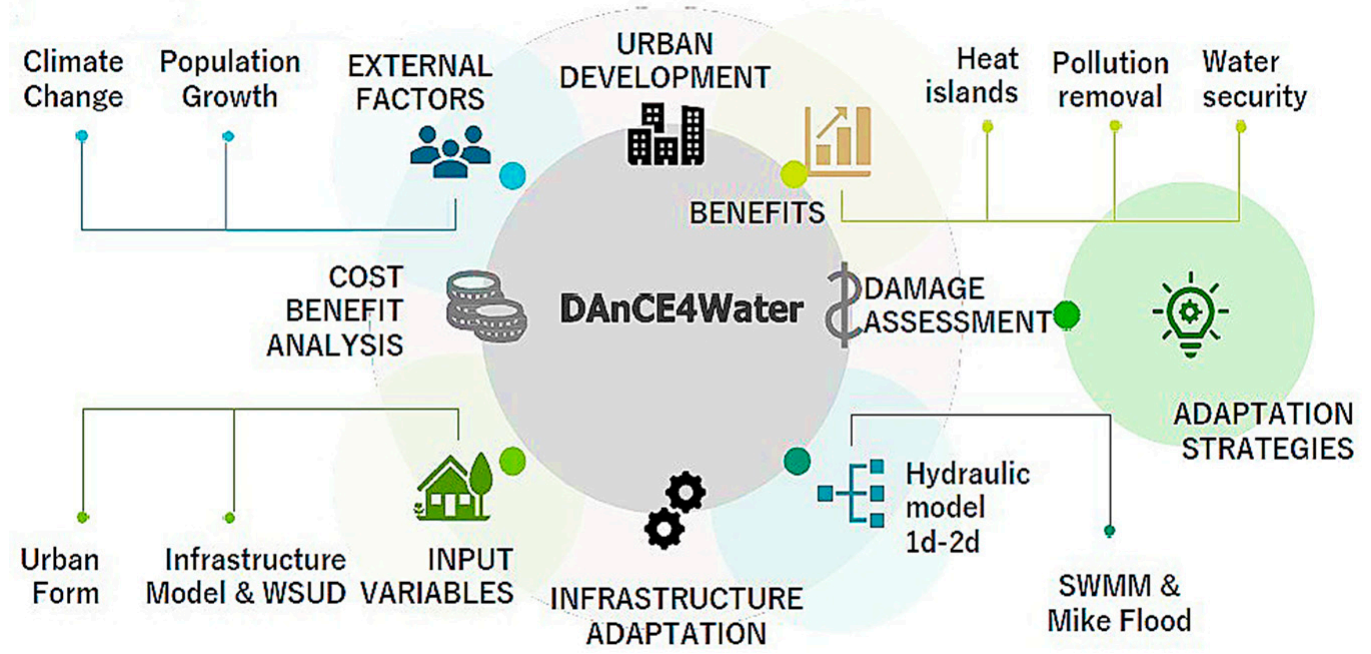

Figure 5. DAnCE4Water module (Adapted with permission from ref. [41] 2021 Elsevier).

DAnCE4Water applies an agent-based approach to simulate the evolution of the urban form at the parcel level and thus directly provides information on the shape and location of urban features, such as buildings or streets [25]. This is possible thanks to the presence of three modules (the Urban Development Module-UDM; the Bio-Physical Model—BPM; 
and the Societal Transition Module-STM) that can be executed, independently of each other, and are rooted in a central unit, or "conductor", which manages the information flow and runs each scenario by storing, managing, and providing required data to the relevant modules. This approach allows for a consideration of spatio-temporal interdependencies between flood hazard, exposure, and vulnerability [27,41].

To allow DAnCE4Water to deliver a reliable answer, a high level of detail is needed, as the information required to place and assess the performance of water infrastructure cannot otherwise be accurately obtained. Common urban planning parameters (derived from planning documents) and demographic information (from census data) are used to establish the new urban form geometry.

The output is therefore a collection of consequential and hypothetical narratives of what future development of the city and of the urban water system could look like within defined constraints.

\section{Results}

\subsection{Hydraulics Results: State-of-the-Art}

For computational and modeling simplicity, simulations were carried out only for the eastern part of the sewer network. Results provided an interesting estimate of the trends of the flows inside the collectors and the flooding of the nodes. In addition, the hydraulic analyses provided information on the flow, in terms of the level, celerity, volume, and time of occurrence of the peak flow. The results are graphically represented using hydrographs (Figure 6).

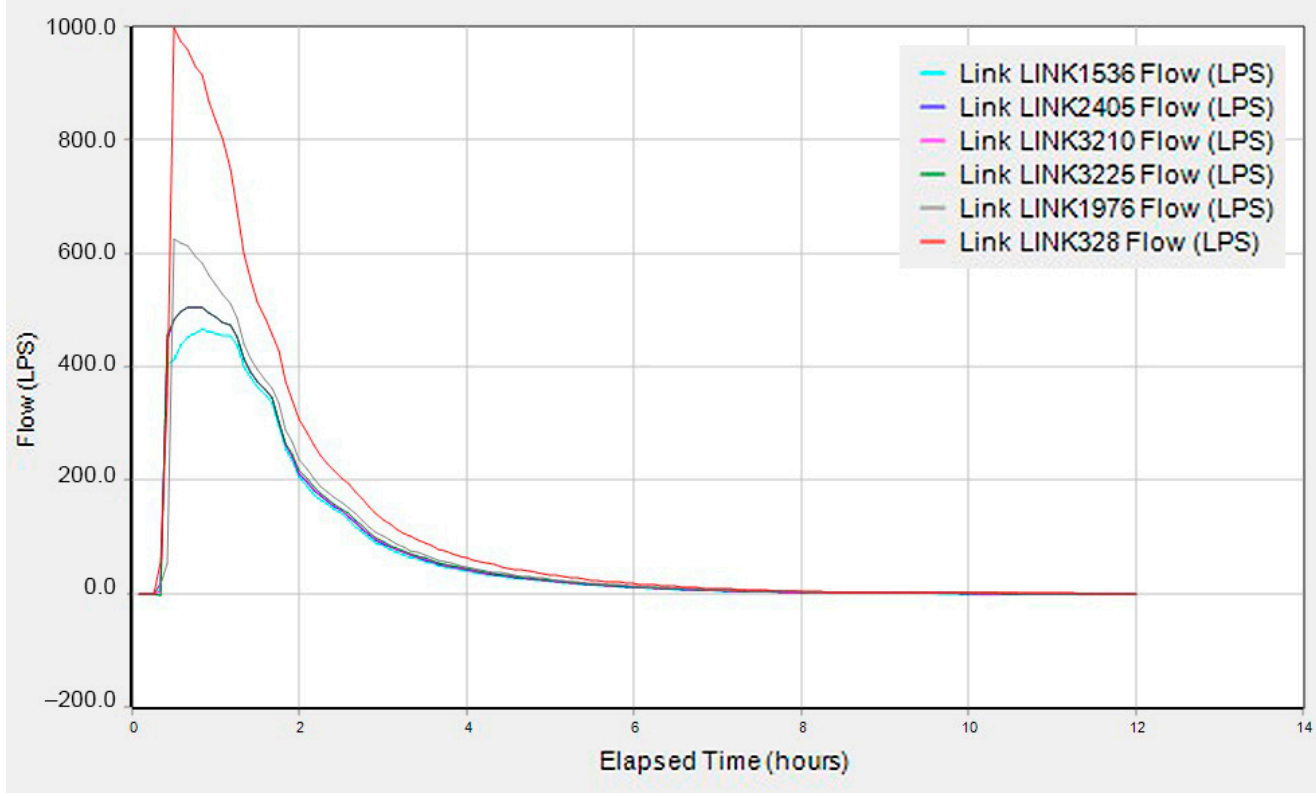

Figure 6. Flow hydrograph: TR = 25 years, Via XXIV Maggio.

The first part of the graph shows an apparently unrealistic trend. The reason for this abrupt rise is due to many combined factors:

- a very short time of concentration;

- high rate of impervious surfaces (high value of runoff coefficient);

- rainfall event with a duration of 1-h only and longer simulation times.

Figure 7 shows the flow level into a section of the sewerage of the Via XXIV Maggio road, which revealed several criticalities in the simulations.

Based on the SWMM simulations, the southeast district of the urban area of Parma showed numerous critical hydraulic issues. Indeed, as illustrated in Figure 8, there are many flood-prone areas and most of the sewer network is under pressure. 


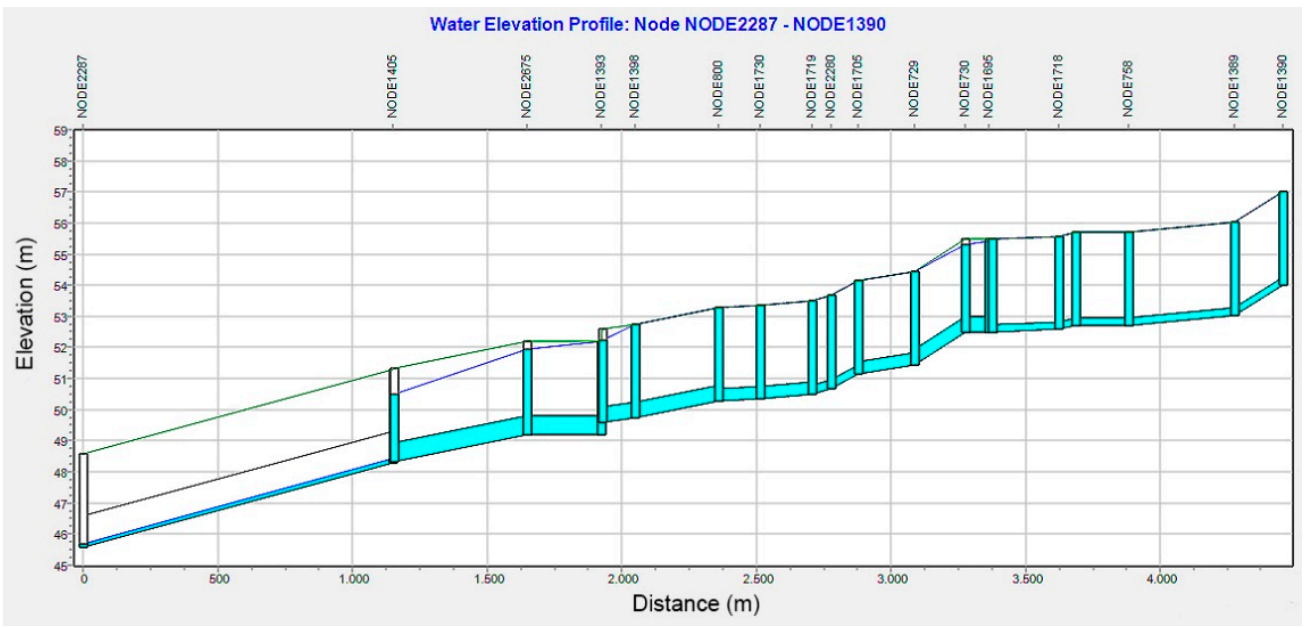

Figure 7. Water elevation profile at the peak moment, $T R=25$ years, Via XXIV Maggio.

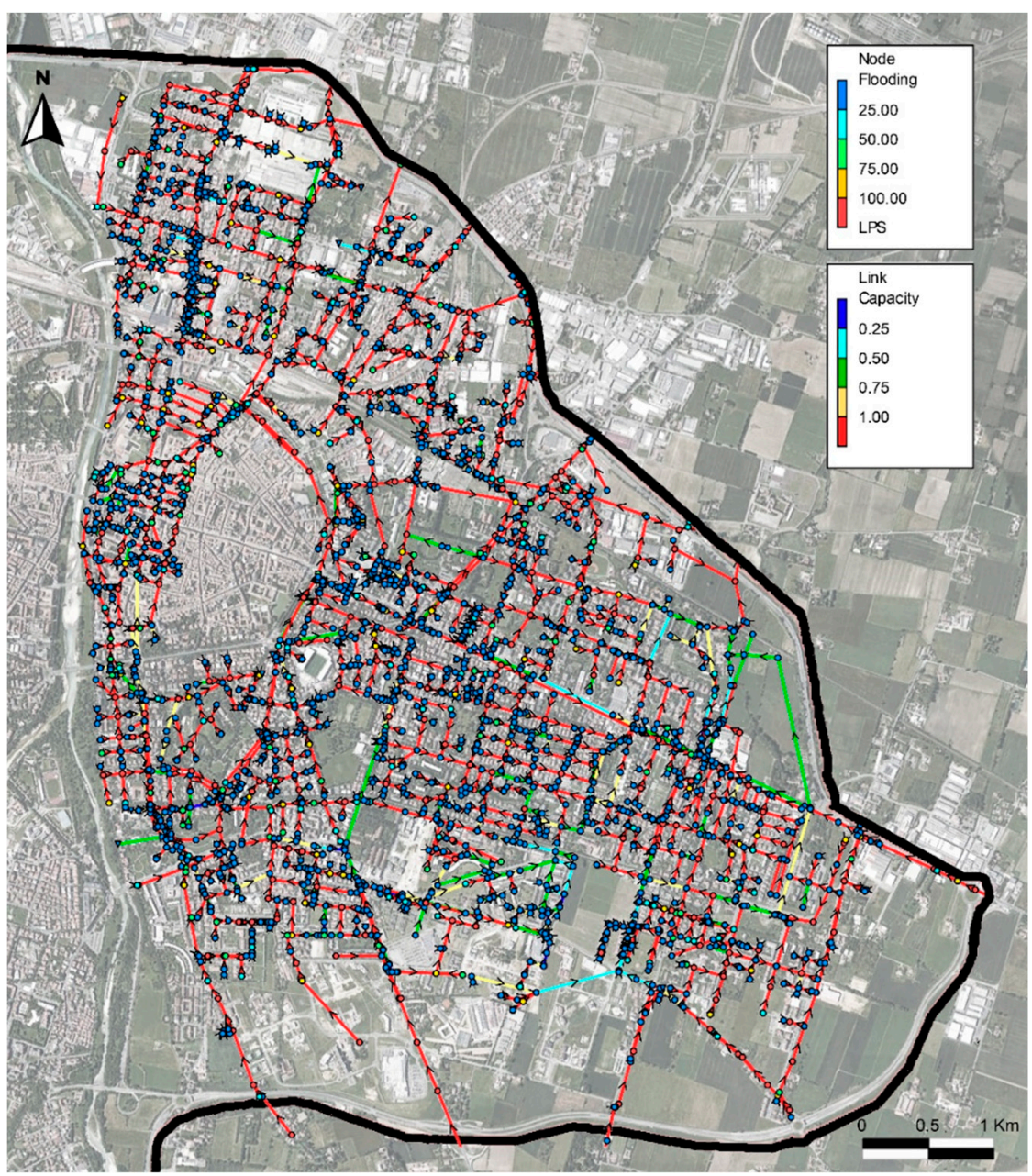

Figure 8. Criticalities of the east part of the sewerage network.

\subsection{DAnCE4Water Results: Comparison among Four Hypotethical Scenarios}

Following the hydraulic simulations of the BAU, the possibility of combining the drainage network with appropriate innovative systems was evaluated as a measure to cope with the increase in surface runoff due to future urbanization and/or climate change. DAnCE4Water was used to simulate and compare the four different scenarios, limited to the southeast area of the urban center (Figure 9). 

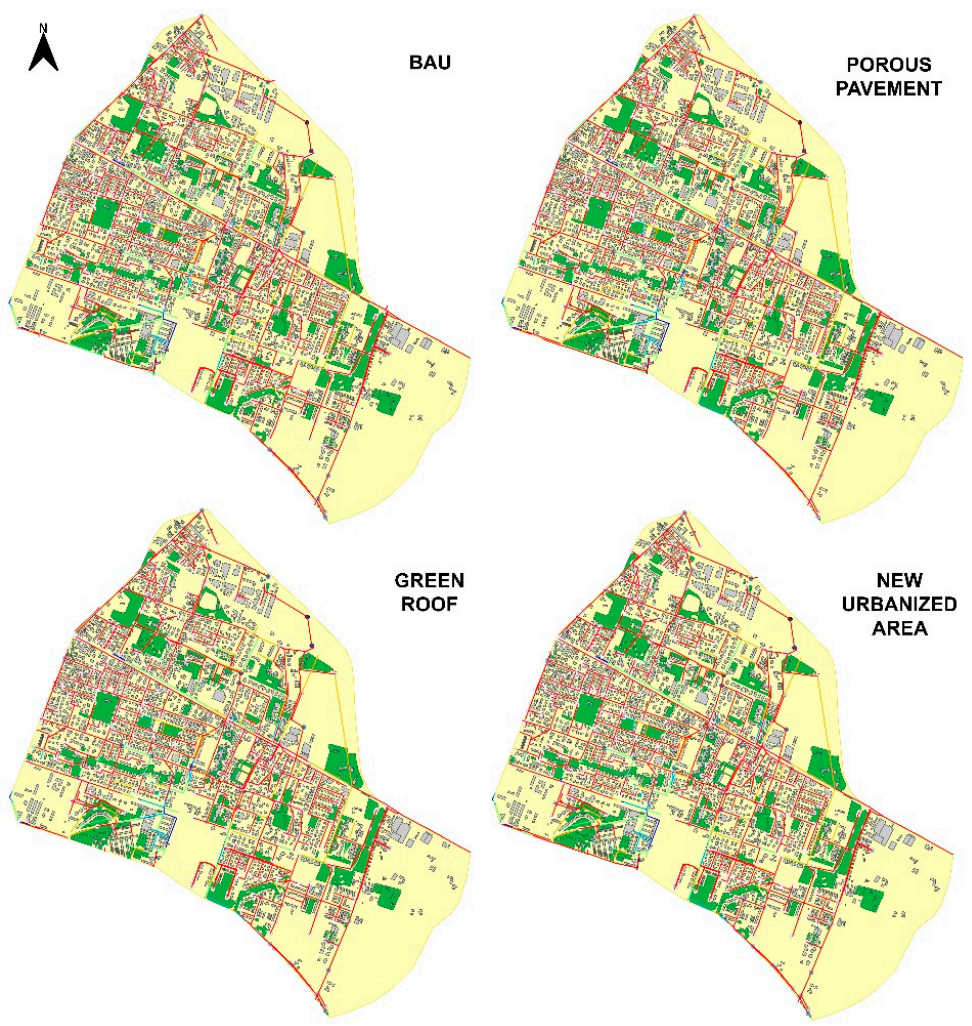

\section{LEGEND}

Performance Assessment

Conduit (capacity)

- $0.04-0.23$

$-0.23-0.42$

$0.42-0.62$

$0.62-0.81$

- $0.81-1$

Performance Aassessment

Junction (flooding volume)

$0-0.037$

$0.037-0.127$

$0.127-0.262$

- $0.262-0.421$

- $0.421-0.682$

- $0.682-1.32$

- $1.32-2.232$

- $2.232-4.142$

- $4.142-8.691$

- $8.691-40.121$

$\square$ Buildings

Green Urban Areas

Case Study Area

Figure 9. Comparison of the four scenarios.

In the comparison between the "BAU" scenario and the "new urbanized area" scenario, apparently there are no differences, although the second one produces more surface runoff. Comparing also "BAU" and "porous pavement" scenarios, the second one reduces surface runoff, though considerable improvements are not evident.

The most significant results were obtained through the implementation of the "green roof" scenario, because of green surfaces promote greater water infiltration and consequently a greater reduction in surface runoff. In Figure 10, a comparison of the "BAU" scenario and the "green roof" scenario is shown in a zoomed location of the southeast area of the urban center: the "BAU" scenario shows a higher number of conduits under pressure.

In fact, in the "green roof" scenario, many of the collectors that were colored in red in the state-of-the-art scenario, become orange or even green. This means that these pipes are no longer under pressure. This is due to the increase in the amount of infiltrated water and the reduction in surface runoff.

The Table 1 shows, in more detail, the different simulation results among the various scenarios.

Table 1. Simulation results for each potential scenario.

\begin{tabular}{|c|c|c|c|c|c|}
\hline SCENARIO & $\begin{array}{c}\text { Total } \\
\text { Precipitation } \\
{[\mathrm{mm}]}\end{array}$ & $\begin{array}{c}\text { Infiltration } \\
\text { Loss }^{2} \\
{[\mathrm{~mm}]}\end{array}$ & $\begin{array}{c}\text { Surface } \\
\text { Runoff }^{3} \\
{[\mathrm{~mm}]}\end{array}$ & $\begin{array}{c}\text { Final } \\
\text { Storage } \\
\text { [mm] }\end{array}$ & $\begin{array}{c}\text { Runoff } \\
\text { Coefficient }^{5} \\
{[-]}\end{array}$ \\
\hline BAU & 24.0 & 1.7 & 19.4 & 2.9 & 0.808 \\
\hline $\begin{array}{c}\text { Porous } \\
\text { Pavement }\end{array}$ & 24.0 & 5.3 & 15.0 & 3.7 & 0.625 \\
\hline Green Roofs & 24.0 & 5.8 & 14.9 & 3.3 & 0.620 \\
\hline $\begin{array}{c}\text { New } \\
\text { Urbanization }\end{array}$ & 24.0 & 1.5 & 19.7 & 2.8 & 0.820 \\
\hline
\end{tabular}

${ }^{1}$ Total precipitation $=$ total rainfall water $[\mathrm{mm}] ;{ }^{2}$ infiltration loss $=$ water flows into the soil $[\mathrm{mm}] ;{ }^{3}$ surface runoff $=$ water flowing over ground cover instead of infiltrating into the underlying soil $[\mathrm{mm}] ;{ }^{4}$ final storage $=$ volume of water conveyed by the drainage network $[\mathrm{mm}] ;{ }^{5}$ runoff coefficient $=$ dimensionless factor that represents the relationship between rainfall and runoff water. 


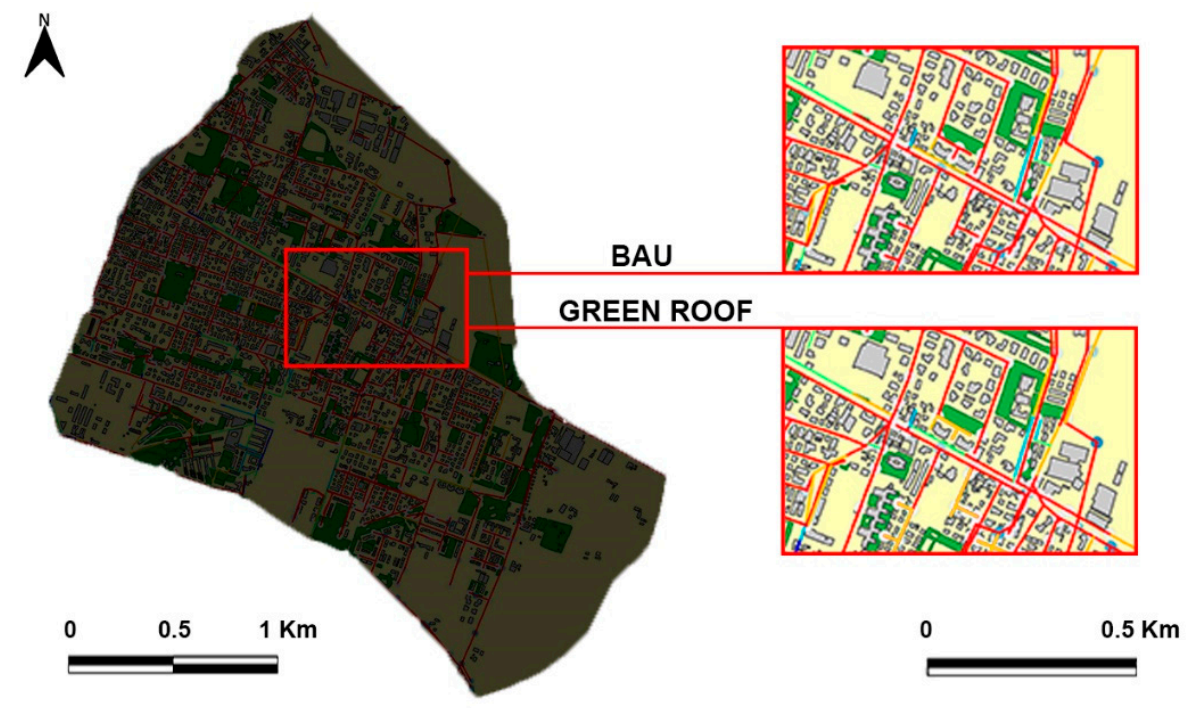

Figure 10. Comparison between "BAU" and "green roof" scenarios.

The graphs below (Figures 11 and 12) show more clearly the differences in terms of infiltration and surface runoff among the scenarios.

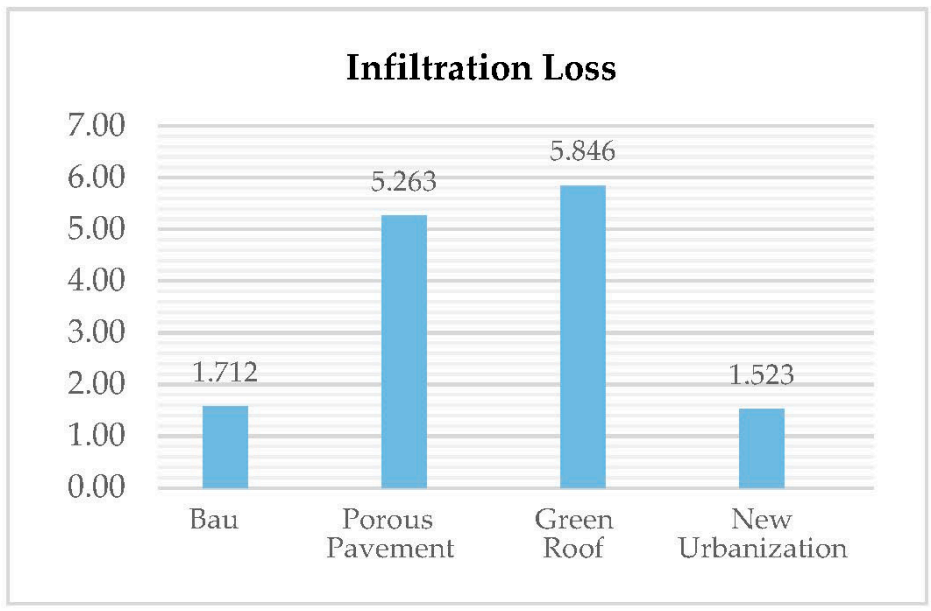

Figure 11. Comparison between infiltration loss results.

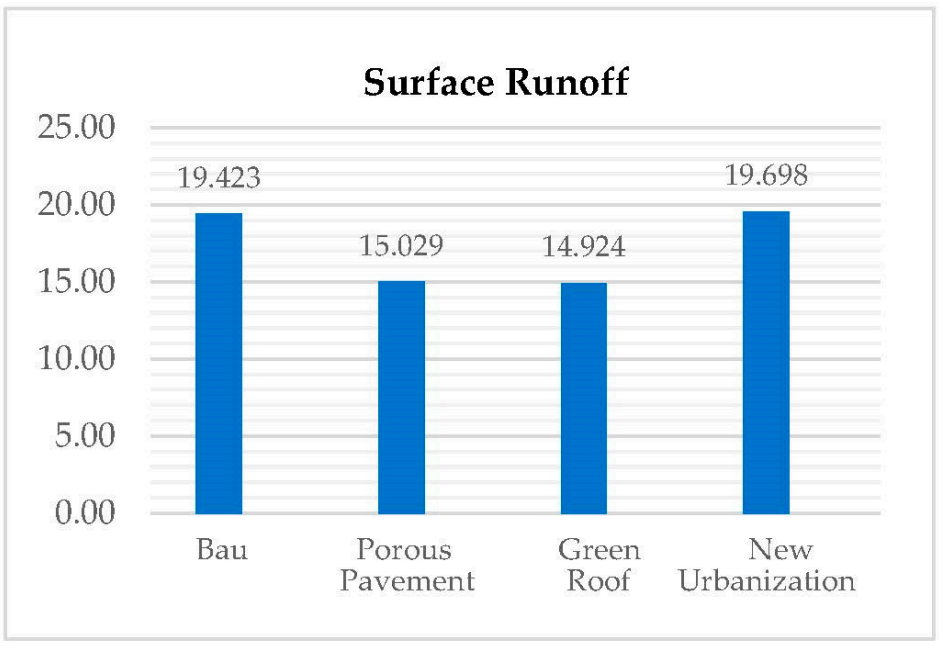

Figure 12. Comparison between surface runoff results. 


\subsection{Simulation of the New Urbanized Area: Fourth Scenario}

In addition to simulating the effectiveness of mitigation measures, DAnCE4Water was used to simulate the urban development assumed in the fourth scenario. The southeast district is mostly a residential catchment with local pockets of other land uses, including larger areas of agriculture spaces.

The catchment has undergone a significant urban development in the last few years and, as indicated in the "Parma Structural Plan", it will be the center of new urban expansions in the coming years.

The location of the new residential urbanization was chosen among those listed in the "Urban Policies" document contained in the project cartography of the "Municipal Structural Plan" of Parma (Figure 13).

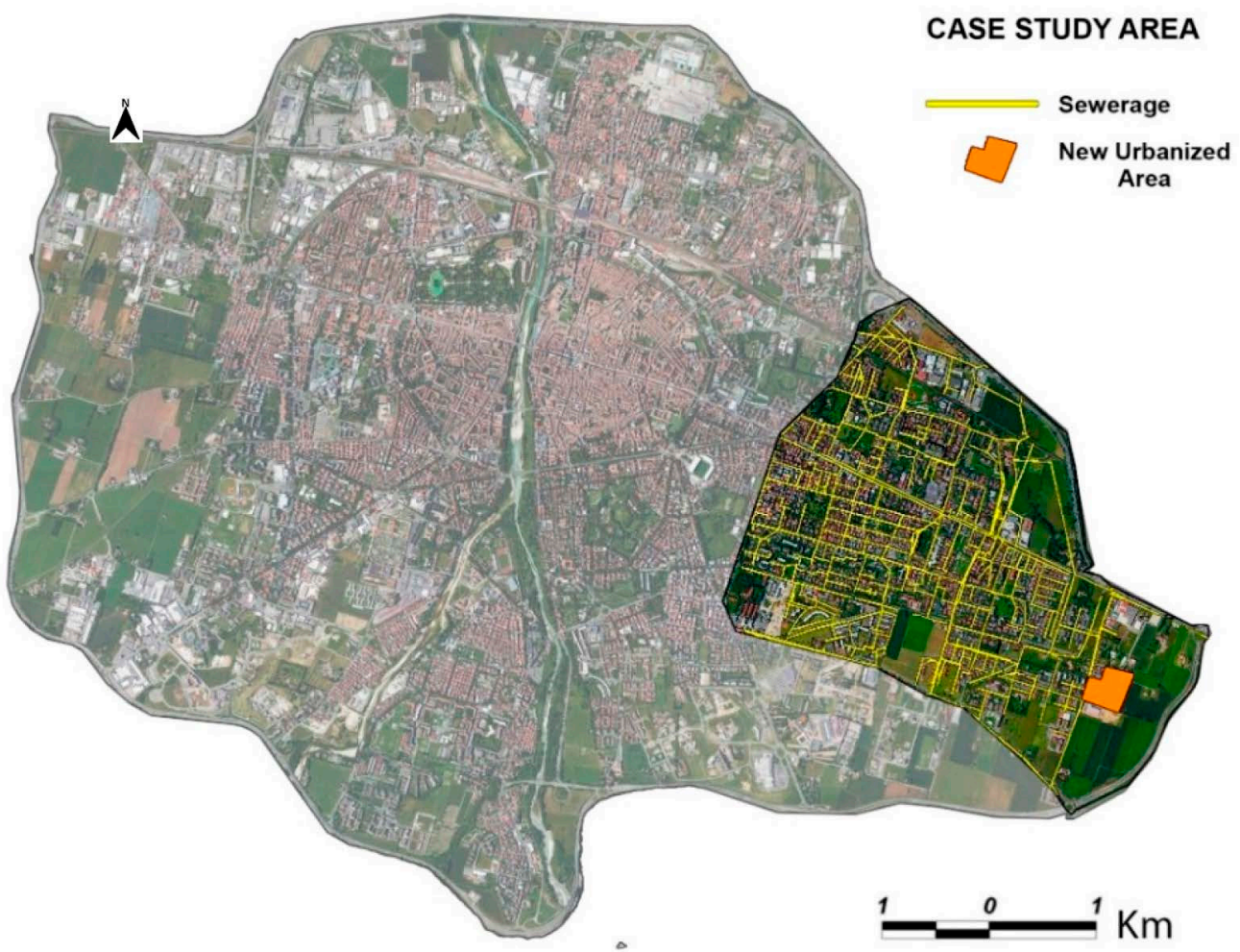

Figure 13. Case study area and sewerage.

To account for the variability in urban forms across the study area, some planning parameters (e.g., city blocks, nature strip, and hardstand fraction) are specified as ranges and are stochastically varied from block to block (Table 2).

Table 2. Model input data.

\begin{tabular}{ccc}
\hline Variables & Unit & Range \\
\hline City Blocks & {$[\mathrm{m}]$} & - \\
Street Offset & {$[\mathrm{m}]$} & - \\
City Parcels & {$[\mathrm{m}]$} & - \\
Building Dimensions & {$[\mathrm{m}]$} & - \\
$\mathrm{N}^{\circ}$ of people per building & - & $0-1$ \\
Hardstand fraction per lots & - & $0-1$ \\
Garden fraction of each building & - & $0-4$ \\
$\mathrm{~N}^{\circ}$ Trees per building & - & - \\
\% of lots with tree & - &
\end{tabular}


Scenario Tools displays a real-time satellite image of the study area, which can then be overlain on the new urban forms generated by the model (Figure 14).

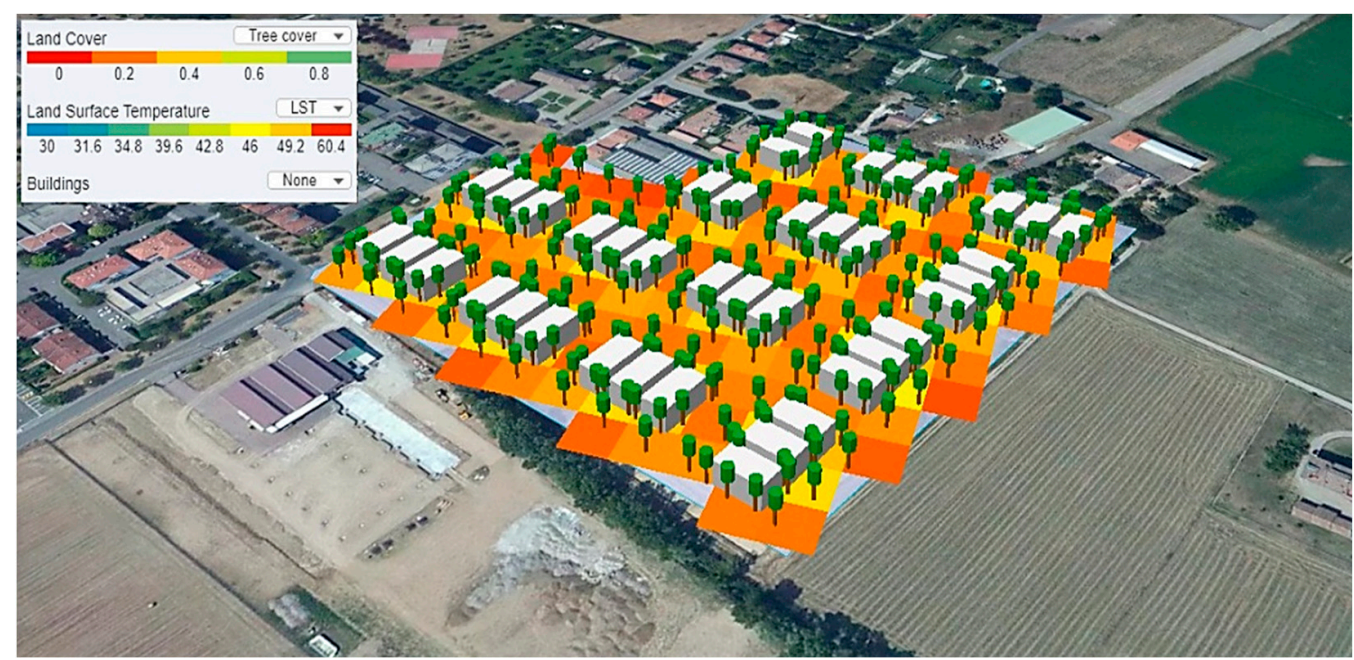

Figure 14. Hypotethical new urbanization generated by the model.

As well as the generated urbanized area, the model shows a gridded map depicting the distribution of impervious area and the land surface temperature, in such a way that it immediately reveals heat islands.

In addition to the maps, for each simulation, the module creates a table (Table 3), which contains the main characteristics of the new urbanized area.

Table 3. Model output data of the new urbanized area.

\begin{tabular}{cc}
\hline Lots Characteristics & Value \\
\hline Area [ha] & 5.5 \\
Impervious Fraction & \\
Impervious Fraction & 0.65 \\
Pervious Fraction & 0.35 \\
Land Cover & \\
Tree Fraction & 0.09 \\
Roof Fraction & 0.16 \\
Road Fraction & 0.43 \\
Concrete Fraction & 0.06 \\
Grass Fraction & 0.06 \\
Water Fraction & - \\
Household & \\
1 & 31 \\
2 & 98 \\
3 & 126 \\
4 & 152 \\
Overview & 407 \\
Population & 160 \\
Households & 44 \\
Parcels & 40 \\
Buildings & 52.28 \\
\hline Land Surface Temperature $\left[{ }^{\circ} \mathrm{C}\right]$ &
\end{tabular}

\section{Discussion}

The purpose of this study is to implement the idea of WSC, applying the DAnCE4Water model to Parma, an Italian town that, in the last few years, has been affected by severe water problems that were mainly related to its sewer network. This case study was also chosen because its features (morphology, size, and population) are similar to those of Elwood, a 
neighborhood in the city of Melbourne, an Australian case study where DAnCE4Water model was applied [42].

Another city where the DAnCE4Water model was implemented is Innsbruck, situated in Austria, in a U-shape valley and with a population of 120,000 inhabitants. In this case study, the dynamics of the UDM and of the BPM modules of the model where analyzed, considering 20 years into the future of city evolution. Urban development was assessed using the population and demographic projections for Innsbruck and an increase in rainfall intensity, as a potential climate change effect, was considered. The use of on-site stormwater infiltration systems was the adaptation strategy adopted to compensate for the impacts of climate change and urban development, but this measure has proved to be insufficient [22-24].

It should be specified that, nowadays, despite a move towards WSC, definite changes in water management practices according to the concept of the integrated urban water management cycle, in line with WSUD principles, have not been fully adopted [43].

The model implemented in this work has allowed the efficiency of new decentralized technologies (WSUD) to be evaluated, which, in this case, are porous pavements and green roofs, as well as their integration with the existing water drainage network.

The first step of this work is related to rainfall surveys and hydrological and hydraulic modeling of the urban area east of the Parma creek, using the SWMM model. This analysis highlighted widespread critical issues on the drainage system due to the insufficiency of the secondary and elementary sewer network and due to the inadequacy of the sections of some of the main collectors. The former is caused by widespread critical issues over the territory for historical reasons. In fact, the city's combined sewer system is mostly made up of collectors, dating back to the early years of the last century. The latter are more local issues and cause more significant flooding events, as a consequence of the large increase of impervious area over the last 20 years. This increase in impervious surface was not followed by an adjustment of the drainage networks, subjecting the city to widespread flooding.

The second step of this work is related to the application of an integrated approach, employing WSUD through the DAnCE4Water model. The southeast district of the urban area, which is a portion of the urban area modeled in SWMM in the first step, was chosen as the area of interest because it showed several critical hydraulic issues. Four different scenarios were evaluated: (1) the business-as-usual scenario (BAU), which considers the actual situation without any adaptation strategy; (2) scenario with green roofs as adaptation strategy; (3) scenario with porous pavements as adaptation strategy; and (4) scenario with new urban development taking into consideration the population increase, but without any adaptation strategies.

The results show that while all scenarios the urban flood risk may be most affected by climate change, due to the frequency increase in sudden and intense rainfall events, even population growth represents a critical element in flood risk assessment. The risk that results from the interaction of hazards, exposure, and vulnerability, can be enhanced by the increase in the exposure of elements that are at risk, such as people and their assets that may be affected by flooding [44]. This can be reduced by a decrease in vulnerability, e.g., Ref. [45].

Indeed, the scenarios that had new urban development and an increase in population reported higher flooding values than the BAU scenario. It can also be noted that the implementation of green roofs and porous pavement significantly reduce surface runoff, and both seem to be similarly efficient in reducing peak flows and, therefore, urban flood risk, as also demonstrated in [46].

Melbourne Water [47] claims that this type of intervention, when correctly applied, could reduce surface runoff by very significant percentages, even greater than $50 \%$.

The findings also show how a lack of interventions and a change in the current stormwater management policies can lead to a worsening of the situation, not only from the hydraulic point of view, but also in relation to surface temperature. As shown in the fourth scenario, a lack of action combined with climate change, urban sprawl, and 
population growth demonstrated a worsening of runoff conditions. On the other hand, due to a lack of data on sewerage flows and a low level of detail about land use, the results should only be considered preliminary outcomes.

\section{Conclusions}

Urban water managers must cope with increasingly complex and multi-faceted challenges, caused by an increase in societal expectations and worsened by the no-longersustainable use of natural resources.

Considering the climate change and population growth challenges that cities are facing, there is an increasing need for economical investment in solutions to deliver longterm sustainable outcomes. Despite commitment by many Italian municipalities, especially in the northern regions, to become water sensitive, the process is still at an early stage and there is a long way to go before the goal is reached. In many cases, old sewer systems are inadequate and adopting nature-based solutions is not yet considered as a priority, even if it is fostered at many levels [18].

This research demonstrates the importance of linking the water sector to other aspects of risk and vulnerability at the city level, leading to an integrated approach and to the concept of WSC. Therefore, the DAnCE4Water model was applied to Parma (North-Central Italy) to promote the development of WSC using WSUD (porous pavements and green roofs) integrated with the existing water drainage network. The results showed the insufficiency of the existing sewer network and the efficiency of WSUD in reducing urban flood risk. It is certainly foreseeable in future scenarios that an increase in the two risk factors, hazard and exposure, due to climate and land use and a reduction in vulnerability is also foreseeable by effectively acting on the re-permeabilization of the impervious surfaces.

The integrated approach adopted for this case study, despite the lack of data, represents an important innovation for planning urban water infrastructure systems under deeply uncertain future scenarios. Although, in this study, the model was only used to evaluate the efficiency of mitigation works in reducing surface runoff, it enables a city to benchmark its current water management practices and policies, helps cities to identify their short and long term goals for water sensitivity, allows to test and evaluate the effectiveness of various strategies through the use of a new modeling software, provides an interesting perspective for more efficient and sustainable interventions, and can reveal a city's strengths and vulnerabilities. Therefore, this work, demonstrated the suitability of the proposed approach, both to solve local problems in the case of critical events at certain points of the sewerage and to plan urban environment redevelopment. Moreover, it contributes to the existing literature on water sensitive cities, which is a current topic in the definition of strategies and actions to make cities resilient to climate change.

Author Contributions: Conceptualization, A.D. and C.U.; methodology, A.D., C.U. and G.G.; software, C.U. and A.D.; validation and formal analysis, A.D. and C.U.; investigation, A.D.; resources, A.D., C.U., M.P., P.P. and G.G.; data curation, A.D.; writing—original draft preparation, A.D. and F.B.; writing-review and editing A.D., F.B. and G.G.; visualization, A.D.; supervision, C.U., M.P. and G.G.; project administration, G.G. All authors have read and agreed to the published version of the manuscript.

Funding: This research received no external funding.

Institutional Review Board Statement: Not applicable.

Informed Consent Statement: Not applicable.

Data Availability Statement: Data can be found in the references cited in the manuscript.

Acknowledgments: The authors thank the Municipality of Parma and the IREN Group for their contribution to providing data and essential information for the success of the project.

Conflicts of Interest: The authors declare no conflict of interest. 


\section{References}

1. Morita, M. Flood risk impact factor for comparatively evaluating the main causes that contribute to flood risk in urban drainage areas. Water 2014, 6, 253-270. [CrossRef]

2. Piro, P.; Maiolo, M.; Talarico, V.C.; Falco, S.; Nigro, G.; Pezzagno, M.; Pavesi, F.C.; Berteni, F.; Grossi, G. Flood risk mitigation in a Mediterranean Urban Area: The case study of Rossano Scalo (CS-Calabria, Italy). In New Trends in Urban Drainage Modelling, Proceedings of the 11th International Conference on Urban Drainage Modelling (UDM 2018), Palermo, Italy, 23-26 September 2018; Mannina, G., Ed.; Springer: Cham, Switzerland, 2018; pp. 339-343. [CrossRef]

3. Ashley, R.M.; Balmforth, D.J.; Saul, A.J.; Blanskby, J.D. Flooding in the future: Predicting climate change, risks and responses in urban areas. Water Sci. Technol. 2005, 52, 265-273. [CrossRef]

4. McGrane, S.J. Impacts of urbanisation on hydrological and water quality dynamics, and urban water management: A review. Hydrol. Sci. J. 2016, 61, 2295-2311. [CrossRef]

5. Grossi, G.; Barontini, S.; Berteni, F.; Balistrocchi, M.; Ranzi, R. Nature-based solutions as climate change adaptation and mitigation measures in Italy. In Climate Change-Sensitive Water Resources; Teegavarapu, R.S.V., Kolokytha, E., Galvão, C.D.O., Eds.; CRC Press: Boca Raton, FL, USA, 2021; pp. 90-100. [CrossRef]

6. Wong, T.H.F.; Brown, R.R. The water sensitive city: Principles for practice. Water Sci Technol. 2009, 60, 673-682. [CrossRef] [PubMed]

7. Hattum, T.; Blauw, M.; Jensen, M.B.; De Bruin, K. Towards Water Smart Cities-Climate Adaptation is Huge Opportunity to Improve the Quality of Life in Cities; Wageningen Environmental Research: Wageningen, The Netherlands, 2016.

8. Bichai, F.; Flamini, A.C. The Water Sensitive City: Implications of an urban water management paradigm and its globalization. WIREs Water 2018, 5, 1-9. [CrossRef]

9. Wong, T.H.F. Water sensitive urban design-The journey thus far. Australas. J. Water Resour. 2015, 10, 213-222. [CrossRef]

10. Wong, T.H.F.; Allen, R.; Brown, R.R.; Deletić, A.; Gangadharan, L.; Gernjak, W.; Jakob, C.; Johnstone, P.; Reeder, M.; Tapper, N.; et al. Stormwater Management in a Water Sensitive City; Cooperative Research Centre for Water Sensitive Cities: Melbourne, Australia, 2013.

11. Zhou, Q. A review of sustainable urban drainage systems considering the climate change and urbanization impacts. Water 2014, 6, 976-992. [CrossRef]

12. Ballard, B.W.; Wilson, S.; Udale-Clarke, H.; Illman, S.; Scott, T.; Ashley, R. The SUDS Manual; CIRIA C753: London, UK, 2015.

13. Cristiano, E.; Farris, S.; Deidda, R.; Viola, F. Comparison of blue-green solutions for urban flood mitigation: A multi-city large-scale analysis. PLoS ONE 2021, 16, e0246429. [CrossRef] [PubMed]

14. Parizotto, S.; Lamberts, R. Investigation of green roof thermal performance in temperature climate: A case study of an experimental building in Florianópolis city, Southern Brazil. Energy Build. 2011, 43, 1712-1722. [CrossRef]

15. Alexandri, E.; Jones, P. Temperature decreases in an urban canyon due to green walls and green roofs in diverse climates. Build. Environ. 2008, 43, 480-493. [CrossRef]

16. Berardi, U.; GhaffarianHoseini, A.; GhaffarianHoseini, A. State-of-the-art analysis of the environmental benefits of green roofs. Appl. Energy 2014, 115, 411-428. [CrossRef]

17. Cipolla, S.S.; Maglionico, M.; Semprini, G.; Villani, V.; Bonoli, A. Green roofs as a strategy for urban heat island mirigation in Bologna (Italy). Acta Hortic. 2018, 1215, 295-300. [CrossRef]

18. Rogers, B.C.; Bertram, N.; Gersonius, B.; Gunn, A.; Löwe, R.; Murphy, C.; Pasman, R.; Radhakrishnan, M.; Urich, C.; Wong, T.H.F.; et al. An Interdisciplinary and catchment approach to enhancing urban flood resilience: A Melbourne case. Philos. Trans. R. Soc. A 2020, 378, 20190201. [CrossRef] [PubMed]

19. De Filippo, D.; Casado, E.S.; Berteni, F.; Barisani, F.; Bautista-Puig, N.; Grossi, G. Assessing citizen science methods in IWRM for a new science shop: A bibliometric approach. Hydrol. Sci. J. 2020, 66, 179-192. [CrossRef]

20. Buytaert, W.; Zulkafli, Z.; Grainger, S.; Acosta, L.; Alemie, T.C.; Bastiaensen, J.; De Bièvre, B.; Bhusal, J.; Clark, J.; Dewulf, A.; et al. Citizen science in hydrology and water resources: Opportunities for knowledge generation, ecosystem service management, and sustainable development. Front. Earth Sci. 2014, 2, 1-21. [CrossRef]

21. Antwi, S.H.; Linnane, S.; Getty, D.; Rolston, A. River basin management planning in the Republic of Ireland: Past, present and the future. Water 2021, 13, 2074. [CrossRef]

22. Urich, C.; Bach, P.M.; Hellbach, C.; Sitzenfrei, R.; Kleidorfer, M.; McCarthy, D.T.; Deletic, A.; Rauch, W. Dynamics of cities and water infrastructure in the DAnCE4Water model. In Proceedings of the 12th International Conference on Urban Drainage, Porto Alegre, Brazil, 10-15 September 2011.

23. Urich, C.; Rauch, W. Exploring critical pathways for urban water management to identify robust strategies under deep uncertainties. Water Res. 2014, 66, 374-389. [CrossRef]

24. Urich, C.; Bach, P.M.; Sitzenfrei, R.; Kleidorfer, M.; McCarthy, D.T.; Deletic, A.; Rauch, W. Modelling cities and water infrastructure dynamics. Proc. Inst. Civ. Eng. Eng. Sustain. 2013, 166, 301-308. [CrossRef]

25. Scenario Tool-CRC for Water Sensitive Cities. Available online: https://www.wsc-scenario.org.au/ (accessed on 2 August 2021).

26. Urich, C.; Sitzenfrei, R.; Kleidorfer, M.; Bach, P.M.; McCarthy, D.T.; Deletic, A.; Rauch, W. Evolution of urban drainage networks in DAnCE4Water. In Proceedings of the 9th International Conference on Urban Drainage Modelling, Belgrade, Serbia, 3-7 September 2012. 
27. Löwe, R.; Urich, C.; Domingo, N.S.; Mark, O.; Deletic, A.; Arnbjerg-Nielsen, K. Assessment of urban pluvial flood risk and efficiency of adaptation options through simulations-A new generation of urban planning tools. J. Hydrol. 2017, 550, 355-367. [CrossRef]

28. IAHR. Available online: https://www.iahr.org/index/detail/337 (accessed on 7 October 2021).

29. Nones, M.; Pescaroli, G. Implications of cascading effects for the EU Floods Directive. Int. J. River Basin Manag. 2016, 14, 195-204. [CrossRef]

30. EU, European Union. Directive 2007/60/CE of the European Parliament and of the Council of 23 October 2007 on the assessment and the management of flood risks. Off. J. L 2007. Available online: https: / / eur-lex.europa.eu/legal-content/EN/TXT/?uri= CELEX:32007L0060 (accessed on 22 September 2021).

31. Comune di Parma. Sistema economico e sociale (SS 1). In PSC 2030-Quadro Conoscitivo-Sistema Ambientale-DCC n.53; Municipality of Parma: Italy, Parma, 2019. (In Italian)

32. Comune di Parma. Suolo e sottosuolo (SA1). In PSC 2030-Quadro Conoscitivo-Sistema Ambientale, Suolo e Sottosuolo-DCC n.53, Municipality of Parma: Italy, Parma, 2019. (In Italian)

33. Comune di Parma. Acque superficiali e sotterranee (SA5). In PSC 2030-Quadro Conoscitivo-Sistema Ambientale, Acque Superficiali e Sotterranee-DCC n.53; Municipality of Parma: Italy, Parma, 2019. (In Italian)

34. Rossman, L.A. Storm Water Management Model User's Manual, SWMM Version 5.1; Water Supply and Water Resources Division, National Risk Management Research Laboratory, U.S. Environmental Protection Agency: Cincinnati, OH, USA, 2015.

35. Maidment, D.R. Handbook of Hydrology, 1st ed.; McGraw-Hill Education: New York, NY, USA, 1993.

36. ARPAE Emilia-Romagna DEXT3R. Available online: https://simc.arpae.it/dext3r/ (accessed on 20 August 2021).

37. Calomino, F.; Paoletti, A. Le Misure di Pioggia e di Portata Nei Bacini Sperimentali Urbani in Italia, 1st ed.; Centro Studi Deflussi Urbani: Milano, Italy, 2004.

38. Paoletti, A. Sistemi di Fognature e Drenaggio: Fondamenti e Nuove Tendenze, 2nd ed.; Cooperativa Universitaria Studio e Lavoro: Milano, Italy, 2010; pp. 4-10.

39. Chow, V.T. Open-Channel Hydraulics, 3rd ed.; McGraw-Hill Book Company: Tokyo, Japan, 1959.

40. Comune di Parma. Fase 2 Analisi idrologiche-idrauliche-Fase 3 Individuazione interventi, A-Relazione generale con stima degli interventi di progetto. In Studio per L'analisi del Rischio Idraulico ed Alluvionale sul Territorio Comunale-DGC n. 372; Municipality of Parma: Parma, Italy, 2015. (In Italian)

41. Rauch, W.; Urich, C.; Bach, P.M.; Rogers, B.C.; de Haan, F.J.; Brown, R.R.; Mair, M.; McCarthy, D.T.; Kleidorfer, M.; Sitzenfrei, R.; et al. Modelling transition in urban water system. Water Res. 2017, 126, 501-514. [CrossRef]

42. Rogers, B.C.; Arnbjerg-Nielson, K.; Bertram, N.; Gunn, A.; Löwe, R.; Murphy, C.; Pasman, R.; Radhakrishnan, M.; Urich, C.; Wong, T.H.F. An integrated approach to enhancing urban flood resilience in Elwood, Melbourne. In Proceedings of the Australian International Water Conference \& Exhibition OzWater, Melbourne, Australia, 10-12 May 2016.

43. Brown, R.; Rogers, B.; Werbeloff, L. Moving Toward Water Sensitive Cities: A Guidance Manual for Strategists and Policy Makers; Cooperative Research Centre for Water Sensitive Cities: Melbourne, Australia, 2016; pp. 10-12.

44. Merz, B.; Aerts, J.; Arnbjerg-Nielsen, K.; Baldi, M.; Becker, A.; Bichet, A.; Blöschl, G.; Bouwer, L.M.; Brauer, A.; Cioffi, F.; et al. Floods and climate: Emerging perspectives for flood risk assessment and management. Nat. Hazards Earth Syst. Sci. 2015, 14, 1921-1942. [CrossRef]

45. Merz, B.; Blöschl, G.; Vorogushyn, S.; Dottori, F.; Aerts, J.C.J.H.; Bates, P.; Bertola, M.; Kemter, M.; Kreibich, H.; Lall, U.; et al. Causes, impacts and patterns of disastrous river floods. Nat. Rev. Earth Environ. 2021, 2, 592-609. [CrossRef]

46. Turco, M.; Brunetti, G.; Palermo, S.A.; Capano, G.; Grossi, G.; Maiolo, M.; Piro, P. On the environmental benefits of a permeable pavement: Metals potential removal efficiency and Life Cycle Assessment. Urban Water J. 2020, 17, 619-627. [CrossRef]

47. Melbourne Water. WSUD Engineering Procedures: Stormwater; CSIRO Publishing: Collingwood, Australia, 2005. 